\title{
Fault slip and modern tectonic stress field in and around Kunming basin*
}

\author{
JING Zhen-jie (荆振杰) DU Yi (杜 义) XIE Fu-ren ${ }^{\dagger}$ (谢富仁) \\ Institute of Crustal Dynamics, China Earthquake Administration, Beijing 100085, China
}

\begin{abstract}
Kunming basin is a Cenozoic faulted basin under the control of mainly SN-trending active faults. In and around the basin, there are a total of eight major active faults. Seismo-geological survey and fault slip observation show that the SN- and NE-trending active faults are mostly sinistral strike-slip faults, while the NW-trending faults are mostly dextral strike-slip faults. Using stress tensor inversion method with 706 active fault striation data at 22 measurement sites, we determined tectonic stress field of the study area. The result shows that modern tectonic stress field in and around Kunming basin is characterized by NNW-SSE compression, ENE-WSW extension, and strike-slip stress regimes. The maximum principal compressional stress $\left(\sigma_{1}\right)$ is oriented $335^{\circ} \sim 2^{\circ}$, with an average dip angle of $21^{\circ}$; the minimum $\left(\sigma_{3}\right)$ is oriented $44^{\circ} \sim 93^{\circ}$, with an average dip angle of $14^{\circ}$, and the intermediate $\left(\sigma_{2}\right)$ has a high, or nearly vertical, dip angle. The inversion result from fault slip data is consistent with the result from focal mechanism solutions.
\end{abstract}

Key words: Kunming basin; fault striation; tectonic stress field CLC number: P315.72 7 Document code: A

\section{Introduction}

Kunming basin, along with its surrounding areas, is located on the southern section of China's north-south seismic zone and the southeastern margin of Sichuan-Yunnan block. It is one of the areas where modern tectonic movements are relatively strong. Under ambient plate action, the crustal stress environment is very complicated and earthquakes have occurred frequently in this area. The study of fault movement and modern tectonic stress field in this area is of great scientific significance to probing into moderate and strong seismic activities and earthquake prediction research.

Previous researches for the estimation of ages and patterns of fault activities, based on structural geology, geomorphology, chronostratigraphy, satellite imagery and paleoearthquake study, show that the study area is dominated by sinistral strike-slip faults (HE et al, 1993; SHEN et al, 1997; JIANG et al, 2003a; YU et al, 2004; QIAO et al, 2004), and results from focal mechanism solutions show that the principal compressional stress of the study area is oriented predominantly NNW-SSE (JIANG et al, 2003b;WANG et al, 2005). These researches have laid a solid foundation for subsequent study on the dynamics of active structures.

Numerous studies on the tectonic stress fields of Sichuan and Yunnan provinces have been conducted by means of stress tensor inversion with fault slip data (XIE et al, 1993, 1994, 2001),

\footnotetext{
* Received 2007-11-02; accepted in revised form 2008-03-17.

Foundation item: Special Fund for Scientific Research Institutions at Central Level (ZDJ2007-8) and a Project sponsored by the Ministry of Science and Technology of P. R. China (2006BAC13B01).

* Author for correspondence: xxiefr@263.net
} 
but few were focused on eastern Yunnan. The vast amount of active fault and sliding structure data of the study area are valuable scientific resources containing dynamic information of the Sichuan-Yunnan block. Based on the previous results of other people, we acquired in this study the striation data of a number of active faults, and by means of stress tensor inversion with the fault slip data, we obtained a set of new data reflecting main features of modern tectonic stress field of the study area.

\section{Active faults in the study area}

Active faults in the study area are very well-developed. The eight major faults are shown in Figure 1. Xiaojiang fault zone $\left(F_{1}\right)$, which is the predominant fault in the area, starts from Qiaojia in the north, and runs along Jinshajiang and Xiaojiang river valleys to the vicinity of Jianshui-Gejiu in the south. It separates into two branch faults from south of Dongchuan, where extend almost parallelly before fanning out at the southern end. The fault zone can be divided into three segments: the northern segment north of Dongchuan (a simplex fault), the middle segment from Dongchuan to Tonghai-Huaning (western and eastern branch faults) and the southern segment from Huaning to Honghe fault (TANG et al, 2006). Xiaojiang fault zone is a late Pleistocene-Holocene $\left(\mathrm{Q}_{4}\right)$ active fault, and is one of the most seismically active zones in China. Other faults in the area include Baiyi-Hengchong fault $\left(F_{2}\right)$, Heilongtan-Guandu fault $\left(F_{3}\right)$, Puduhe-Xishan

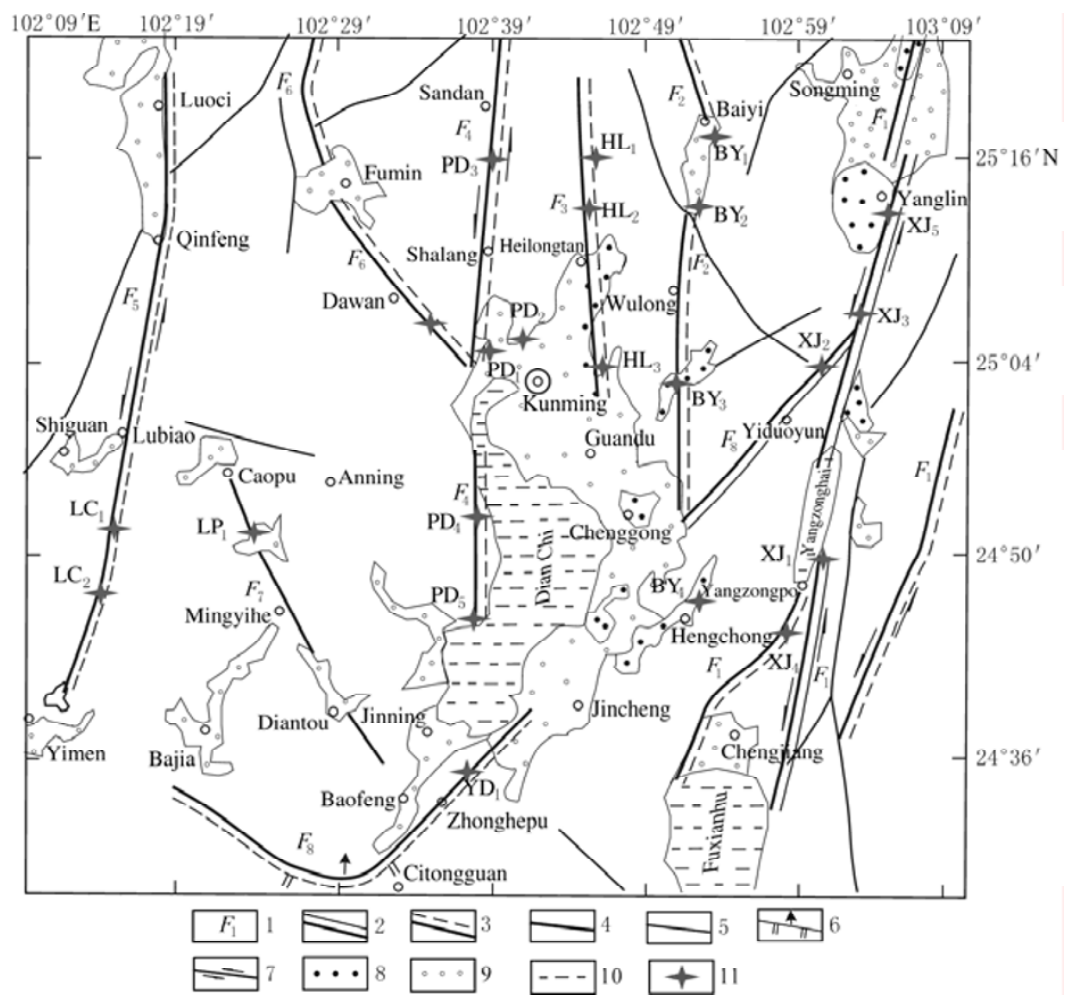

Figure 1 Active faults in study region (According to YU et al, 2004)

1. Serial number of major fault; 2 . Holocene active fault; 3. Late Pleistocene active fault; 4. Early-mid Pleistocene active fault; 5 . Other fault; 6 . Thrust fault; 7. Strike-slip fault; 8. Quaternary sediment; 9 . Tertiary sediment; 10 . Water system; 11 .Measurement site 
fault $\left(F_{4}\right)$ and Luoci-Yimen fault $\left(F_{5}\right)$. These are all nearly SN-trending faults, along which develop such structures physiognomys as trough valleys, relic mountains and faulted river systems. The faults along the faulted rivers, characterized by sinistral slip, are mid-late Pleistocene $\left(\mathrm{Q}_{3}\right)$ active faults (YU et al, 2004). Besides, there are the NW-trending Fumin-Chenggong fault $\left(F_{6}\right)$ and Caopu-Mingyihe fault $\left(F_{7}\right)$, and the NE-trending Yiduoyun-Dachunhe fault $\left(F_{8}\right)$.

The orientations of major active faults in this area are correspondent with their movement modes. Most of the faults are high-angle, SN-trending, strike-slip faults. The SN- and NE-trending faults are mostly sinistral strike-slip faults, while the NW-trending ones are mostly dextral strike-slip faults. Besides the major faults, there are other active faults widely distributed in the study area: some intersect obliquely with, branch out from, or extend parallel to the major faults, and some are in an echelon arrangement, all with different configurations and scales. These faults and the major faults are organically combined, in one tectonic stress field.

\section{Stress tensor inversion method with fault slip data}

By this method, the tectonic stress tensor prompting tectonization is determined on the basis of fault slip resulting from latest tectonic motion, structural features from paleoearthquakes and surface rupture caused by earthquakes. The method turned conventional qualitative tectonic analysis to modern computerized quantitative analysis. The result obtained with this method represents latest tectonic disturbance of the upper crust, i.e., tectonic stress resulting from modern tectonic motion. Geologically speaking, the present day is part of the modern times, i.e., modern times involve the present day. Study reveals that modern tectonic stress field appears stable during certain geological periods (XIE et al, 1993, 2004). At present, the stress tensor inversion method with fault slip data has been widely used in tectonic stress field analysis (Angelier, 1979; Etchcopar et al, 1981; Gaais et al, 2000; Garcia et al, 2002; Yamaji et al, 2006; XU et al, 1984; XIE et al, 1989, 2001; ZHANG et al, 2006).

With this method, the tectonic stress state in the areas where the faults lie is estimated on the basis of fault observation data which contain fault motion features. The essence of the method lies with the fitting of slip direction by the calculated shear stress direction on the section (hence it is also referred to as slip direction fitting method), which eventually yields four characteristic parameters of the stress tensor: three principal stress directions and one stress factor representing relative quantitative relation between the principal stresses $R\left[R=\left(\sigma_{2}-\sigma_{3}\right) /\left(\sigma_{1}-\sigma_{3}\right)\right]$.

\section{Fault striation observation}

We carried out field investigation on a great number of active faults in the study area and conducted systematic survey on fault striation. The result shows that all fault striations are the results of fault slip since late Quaternary Period, because most of the faults directly dislocate the Quaternary strata and the striations are detected in the strata since the Quaternary Period. The other active faults clearly dislocate rivers, gullies, proluvial fans and river terraces, yet neither intact sections nor clear striations are likely to remain due to looseness of the dislocated matters. However, tracing along faults unveils new sections with clear striations at bedrock outcrops and the fault motion features reflected by striation correspond with geomorphic features of dislocation, therefore, it is obvious that the striations are the results of recent fault activities (XIE et al, 1994).

In the field survey, we chose altogether 28 sites for fault striation measurement and acquired a total of 706 fault slip data. According to the trends of faults where the sites are located, the 22 
sites reflecting modern tectonic stress field are divided into the following three groups.

Group 1: Measurement sites for SN-trending faults

In the study area, HL1 HL3, PD1 PD5, BY1 BY4, LC1 LC2, XJ2 XJ3 and XJ5 are measurement sites for SN-trending faults. Among them, HL1 HL3 are located on Heilongtan-Guandu fault $\left(F_{3}\right)$, PD1 PD5 on Puduhe-Xishan fault $\left(F_{4}\right)$, BY1 BY4 on Baiyi-Hengchong fault $\left(F_{2}\right)$, LC1 LC2 on Luoci-Yimen fault $\left(F_{5}\right), \mathrm{XJ} \sim \mathrm{XJ} 3$ and XJ5 on the middle segment of Xiaojiang fault $\left(F_{1}\right)$ (Figure 1).

The SN-trending faults strikes $350^{\circ} \sim 10^{\circ}$, with high dip angles and low, or nearly horizontal, striation rakes, indicating sinistral strike-slip fault motion. Most of the fault striations appear in recent strata, e.g. clear striations are observed on the section of late Pleistocene loess at Ciba (HL1 site) on Heilongtan fault (Figure 2a); clear horizontal striations are found in the laterite $\left(\mathrm{Q}_{3}\right)$ at Yelianchang (PD2 site) on Puduhe-Xishan fault, suggesting sinistral horizontal motion (Figure 2b); the Luoci-Yimen fault dislocated the gully by about $60 \mathrm{~m}$ at Dongcun as a result of its sinistral motion (Figure 2c), and it vertically dislocated the loess by $2 \mathrm{~m}$ at Shuijiejing (PD3 site) where the section crops out (Figure 3).

Group 2: Measurement sites for NE-trending faults

$\mathrm{XJ} 1$ and XJ4 measurement sites are located in the south of the middle segment of Xiaojiang fault $\left(F_{1}\right)$, which strikes around $30^{\circ}$, with a high dip angle and low striation rake. Clear horizontal

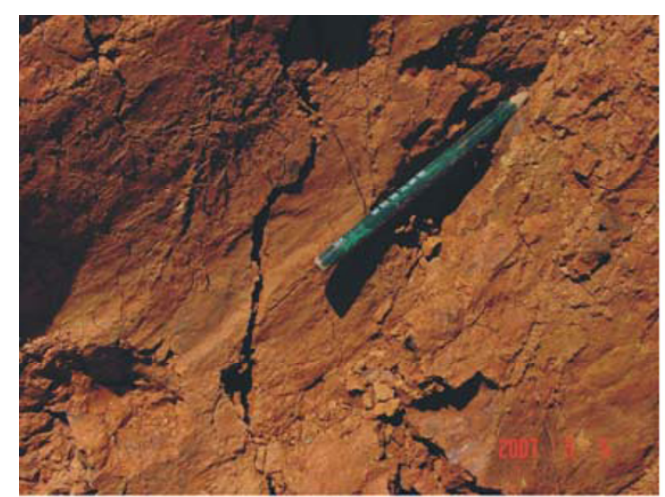

(a)

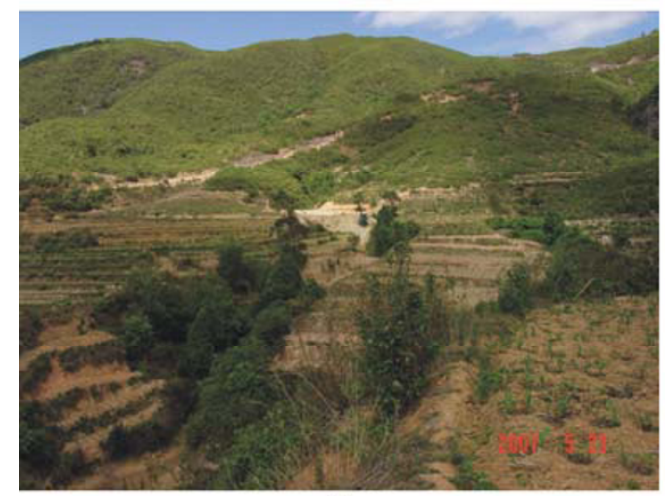

(c)

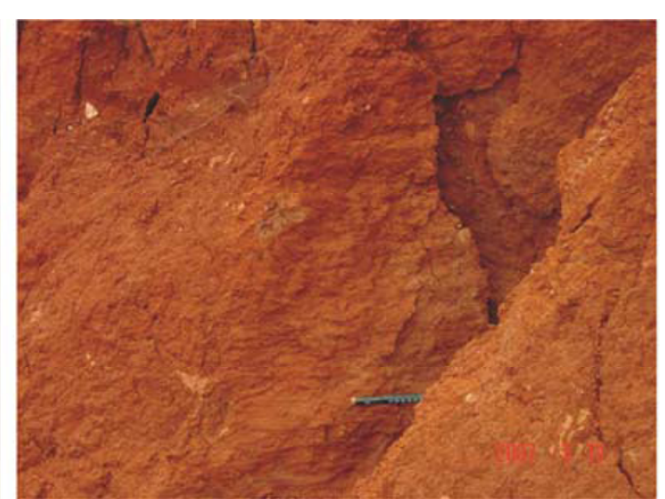

(b)

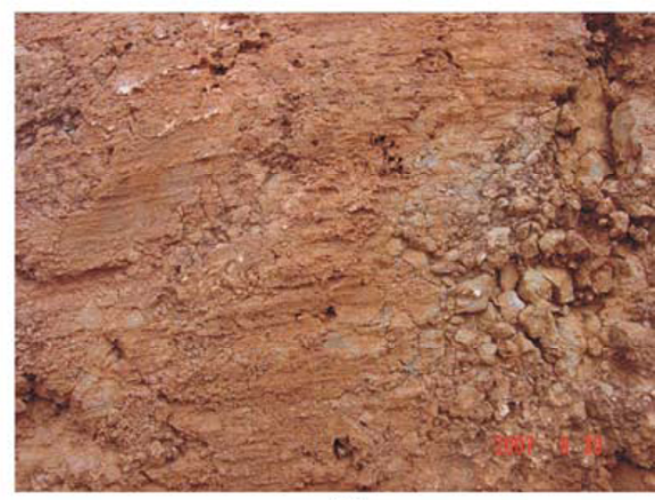

(d)

Figure 2 Slicken-slide pictures of field observation in kunming and adjacent area

(a) Slicken-slides on Ciba section of Heilongtan fault; (b) Slicken-slides on a section of Yunnan smeltery; (c) Luoci-Yimen fault left-lateral fault shifting a trench; (d) Slicken-slides on a section of Xiaojiang fault 
striations are observed in the semi-cemented gravel bed on Mazhuang section (XJ4 site) (Figure 2d), indicating sinistral strike-slip fault motion. Most of the striations appear in recent strata, some on bedrock surface. YD1 site is located on Yiduoyun-Dachunhe fault $\left(F_{8}\right)$, which has a relatively low dip angle.

Group 3: Measurement sites for WNW-trending faults

CP1 site is located on Caopu-Mingyihe fault $\left(F_{7}\right)$ and YL1 on Fumin-Chenggong fault $\left(F_{6}\right)$, which strikes NW $330^{\circ}$, with a dip angle $60^{\circ} \sim 80^{\circ}$. At the outcrop of Fumin-Chenggong fault (YL1 site), laterite $\left(\mathrm{Q}_{3}\right)$ is found on one side of the fault while bedrock is found on the other, and clear striations can be seen on the smooth laterite surface. The small rake of the fault suggests its dextral strike-slip motion (Figure 4).

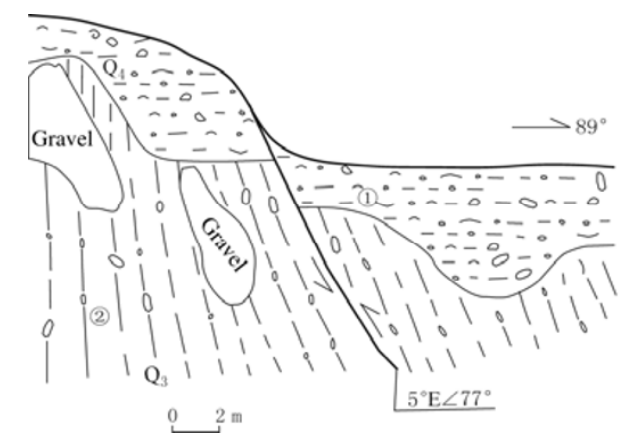

Figure 3 Fault section at Shuijiejing (1) Loess; (2) Gravelly loess

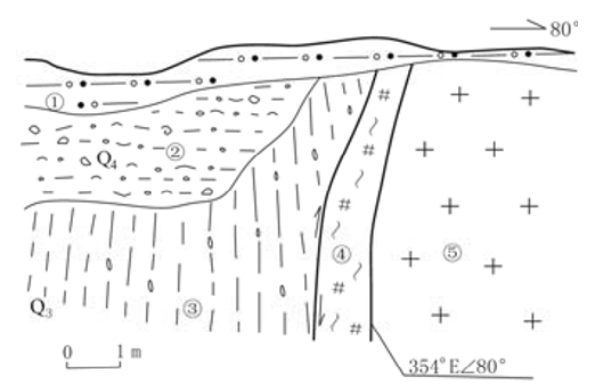

Figure 4 Fault section at Yangliuhe (1) Surface soil; (2) Loess; (3) Laterite; (4) Fault fragment; (5) Granite

\section{Calculation result}

There are originally a total of 28 sites for field observation in this study, but two of them are excluded owing to their inadequate data which lead to great discrepancy between the results; another four are not taken into consideration because they provide samples of probably early structural features and the calculation results differ obviously from modern tectonic stress field. Results from the other 22 sites all reflect quite well the characteristics of stress field in the study area (Figure 5; Table 1). Inversion result from each of the 22 sites presents a mean deviation angle between fault striation $S$ and the fitted shear stress direction $\tau$ on the section (Table 1). The credibility of the fitted stress tensor can be determined by the mean deviation angle. It is generally believed that when the mean deviation angle between $S$ and $\tau$ is smaller than $20^{\circ}$, the fitted stress tensor is reliable; when it is $20^{\circ} \sim 45^{\circ}$, the stress tensor is considered acceptable and when it is larger than $45^{\circ}$, the stress tensor is considered unacceptable (XIE et al, 1994). In this study, the mean deviation angle is mostly $2^{\circ} \sim 20^{\circ}$, which can be regarded as desirable, however, at HL2, HL3 and XJ4 sites the stress tensor is merely acceptable.

The calculation results show that modern tectonic stress field in and around Kunming basin is characterized by NNW-SSE compression and ENE-WSW extension (Figure 5, Table 1). The maximum principal compressional stress $\left(\sigma_{1}\right)$ is oriented $335^{\circ} \sim 2^{\circ}$, with an average dip angle of $21^{\circ}$; the minimum $\left(\sigma_{3}\right)$ is oriented $44^{\circ} \sim 93^{\circ}$, with an average dip angle of $14^{\circ}$, and the intermediate $\left(\sigma_{2}\right)$ has a relatively high dip angle. The stress regimes are all of strike slip and stress direction is hori- 
zontal. Statistics of the orientations of maximum compressional stress $\left(\sigma_{1}\right)$ and minimum compressional stress $\left(\sigma_{1}\right)$ (Figure 6) shows consistency of the calculation results, suggesting stable tectonic stress field of the study area since late Quaternary Period.
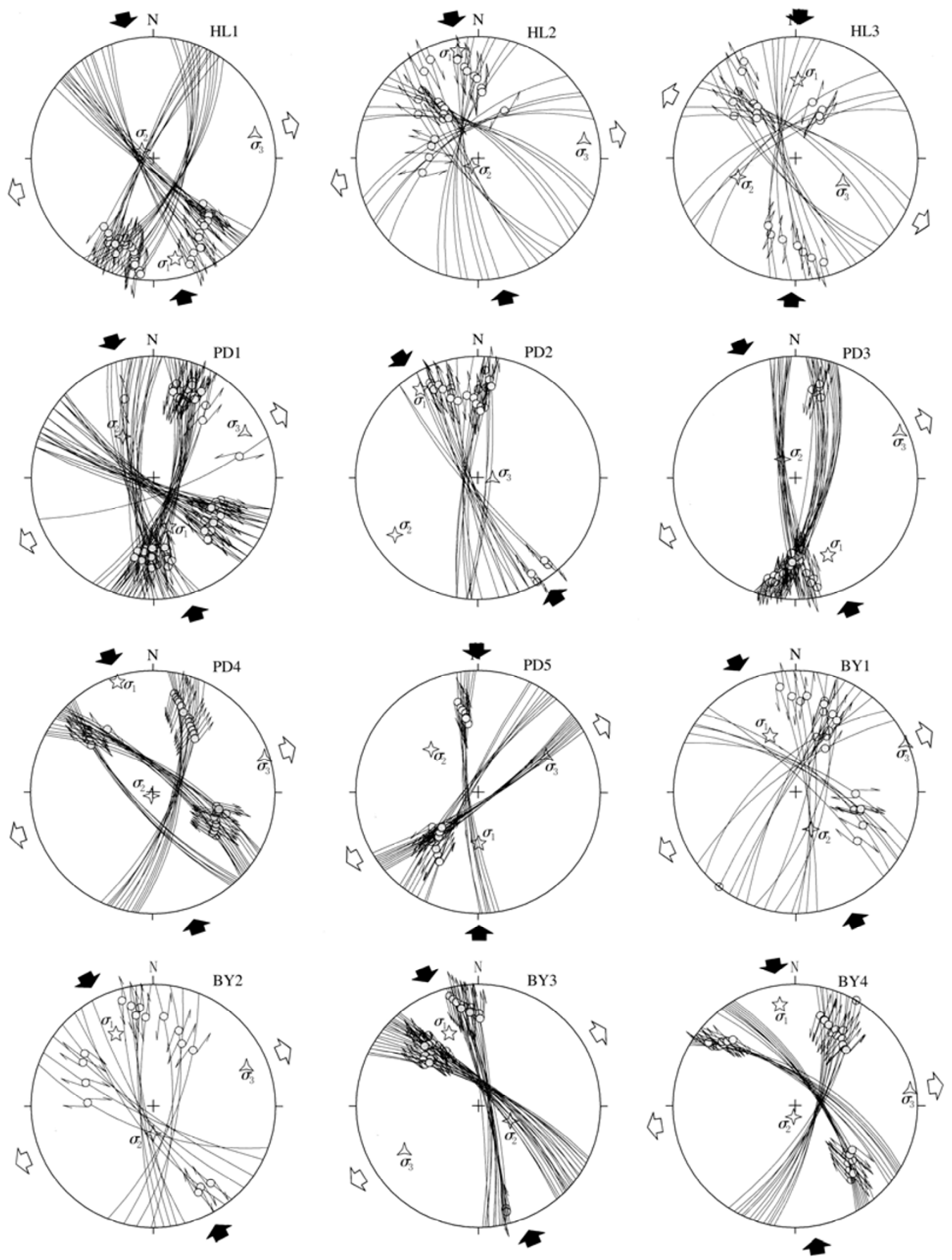

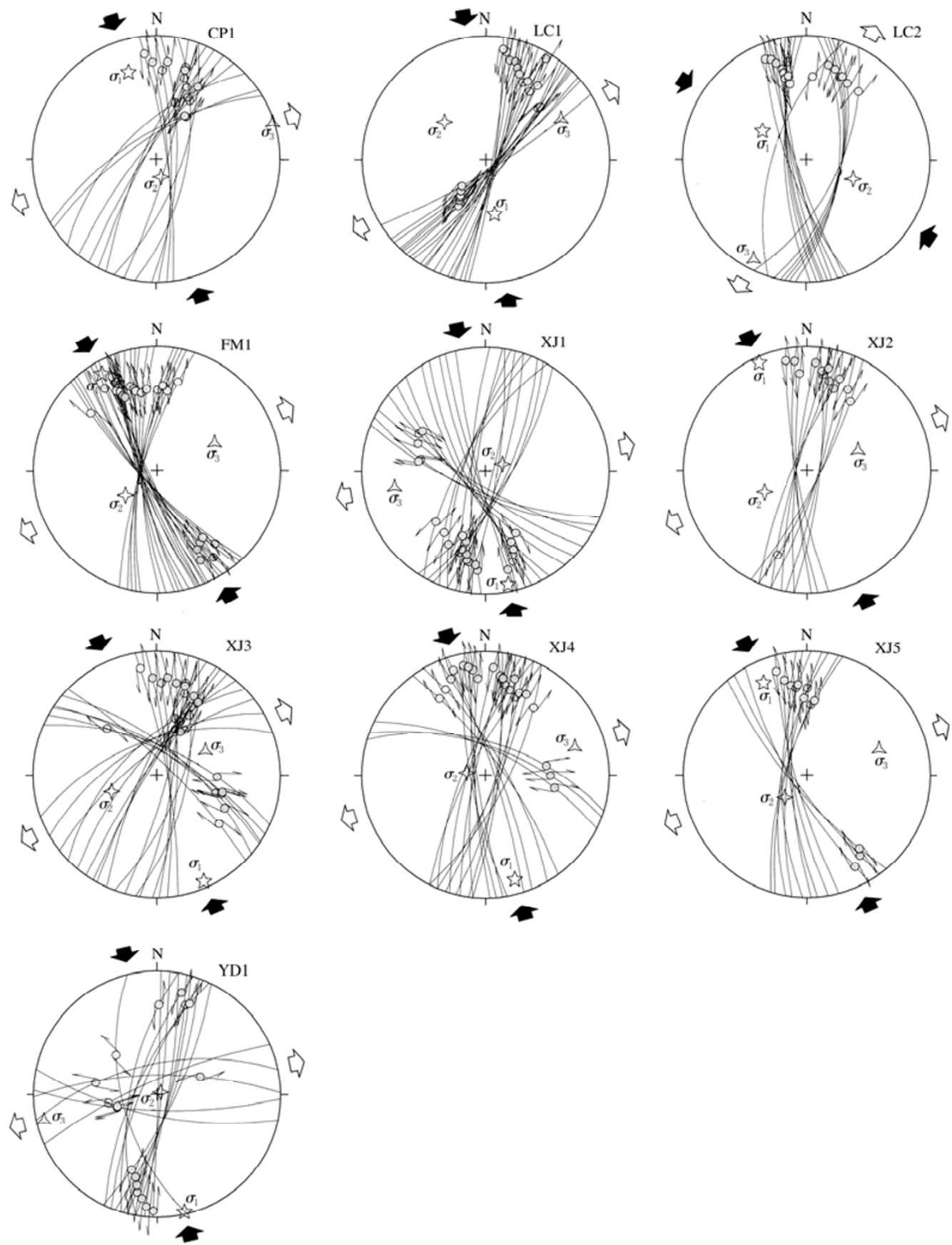

Figure 5 Lower hemisphere Wulff net projection of the calculated stress tensors for every measure site Bold arrows indicate the direction of maximum compression (inward) or maximum tension (outward); Small arrows along arc indicate the direction of slicken-slide; Triangle, square, and pentagon represent $\sigma_{1}, \sigma_{2}$ and $\sigma_{3}$ respectively; code denote measuring sites 
Table 1 Characteristics of modern tectonic stress tensor in and around Kunming basin

\begin{tabular}{|c|c|c|c|c|c|c|c|c|c|c|c|c|}
\hline \multirow[b]{2}{*}{ Site code } & \multirow[b]{2}{*}{ Site name } & \multicolumn{2}{|c|}{ Site position } & \multicolumn{2}{|c|}{$\sigma_{1}$} & \multicolumn{2}{|c|}{$\sigma_{2}$} & \multicolumn{2}{|c|}{$\sigma_{3}$} & \multirow{2}{*}{$\begin{array}{c}\text { Stress } \\
\text { factor } R\end{array}$} & \multirow{2}{*}{$\begin{array}{c}\text { Average } \\
(s, \tau)^{*}\end{array}$} & \multirow{2}{*}{$\begin{array}{l}\text { Stress } \\
\text { regime }\end{array}$} \\
\hline & & $\lambda_{\mathrm{E}} /^{\circ}$ & $\varphi_{\mathrm{N}} /^{\circ}$ & $\begin{array}{l}\text { Azi- } \\
\text { muth }\end{array}$ & Dip & $\begin{array}{l}\text { Azi- } \\
\text { muth }\end{array}$ & Dip & $\begin{array}{l}\text { Azi- } \\
\text { muth }\end{array}$ & Dip & & & \\
\hline HL1 & Ciba & 102.73 & 25.16 & 168 & 10 & 305 & 77 & 76 & 9 & 0.184 & 8 & Strike slip \\
\hline HL2 & Shiguannan & 102.73 & 25.20 & 2 & 24 & 252 & 37 & 87 & 43 & 0.215 & 22 & Strike slip \\
\hline HL3 & Renqiying & 102.74 & 25.08 & 349 & 6 & 220 & 80 & 80 & 7 & 0.461 & 44 & Strike slip \\
\hline PD1 & Haiyuansi & 102.63 & 25.09 & 163 & 44 & 323 & 44 & 63 & 10 & 0.612 & 12 & Strike slip \\
\hline PD2 & Yelianchang & 102.68 & 25.09 & 327 & 8 & 236 & 11 & 93 & 76 & 0.154 & 16 & Strike slip \\
\hline PD3 & Shuijiejing & 102.66 & 25.13 & 157 & 21 & 326 & 69 & 66 & 4 & 0.339 & 8 & Strike slip \\
\hline PD4 & Longmencun & 102.62 & 24.98 & 351 & 10 & 188 & 80 & 82 & 3 & 0.552 & 10 & Strike slip \\
\hline PD5 & Guanyinshan & 102.66 & 24.84 & 180 & 44 & 313 & 35 & 62 & 25 & 0.419 & 15 & Strike slip \\
\hline BY1 & Songhuaba & 102.85 & 25.19 & 335 & 36 & 157 & 54 & 66 & 1 & 0.696 & 15 & Strike slip \\
\hline BY2 & Miaoshanpo & 102.85 & 25.13 & 332 & 23 & 181 & 65 & 67 & 11 & 0.158 & 19 & Strike slip \\
\hline BY3 & Tongniusi & 102.83 & 25.03 & 338 & 25 & 115 & 58 & 239 & 19 & 0.221 & 4 & Strike slip \\
\hline BY4 & Hengchong & 102.84 & 24.78 & 342 & 3 & 200 & 86 & 72 & 2 & 0.867 & 11 & Strike slip \\
\hline $\mathrm{CP} 1$ & Wayaocun & 102.38 & 24.91 & 342 & 17 & 165 & 73 & 72 & 1 & 0.260 & 6 & Strike slip \\
\hline $\mathrm{LC} 1$ & Dongcun & 102.24 & 24.87 & 171 & 42 & 312 & 41 & 61 & 21 & 0.533 & 18 & Strike slip \\
\hline $\mathrm{LC} 2$ & Shuiqiao & 102.21 & 24.79 & 129 & 53 & 317 & 37 & 224 & 4 & 0.290 & 2 & Strike slip \\
\hline FM1 & Yangliuhe & 102.57 & 25.11 & 330 & 6 & 232 & 54 & 65 & 36 & 0.175 & 15 & Strike slip \\
\hline $\mathrm{XJ} 1$ & Maitianwan & 102.98 & 25.85 & 169 & 3 & 67 & 73 & 260 & 17 & 0.349 & 34 & Strike slip \\
\hline $\mathrm{XJ} 2$ & Laoyutun & 103.06 & 25.18 & 336 & 3 & 243 & 48 & 69 & 42 & 0.177 & 11 & Strike slip \\
\hline $\mathrm{XJ} 3$ & Lizijing & 103.11 & 25.11 & 156 & 3 & 250 & 47 & 63 & 42 & 0.418 & 16 & Strike slip \\
\hline XJ4 & Mazhuang & 102.97 & 24.79 & 156 & 7 & 278 & 73 & 73 & 16 & 0.434 & 24 & Strike slip \\
\hline XJ5 & Xiaodongshan & 103.08 & 25.22 & 335 & 11 & 224 & 61 & 70 & 26 & 0.274 & 8 & Strike slip \\
\hline YD1 & Dachunhe & 102.58 & 24.57 & 167 & 1 & 59 & 86 & 257 & 4 & 0.240 & 20 & Strike slip \\
\hline
\end{tabular}

Note: $(s, \tau)^{*}$ is the mean deviation angle between the slip vector and fitted shear stress.
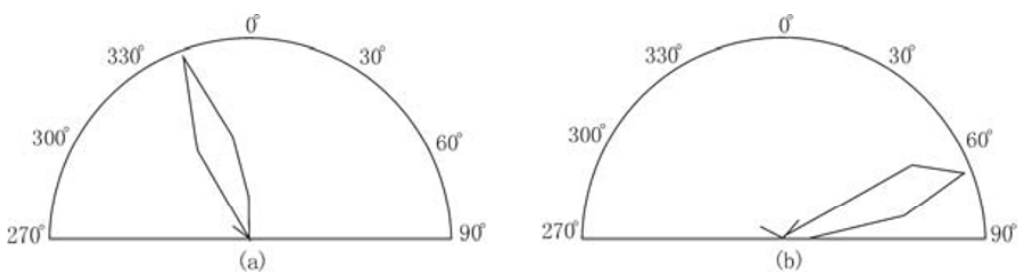

Figure 6 Statistical analysis of the calculation results

(a) Statistics of azimuths of $\sigma_{1}$; (b) Statistics of azimuths of $\sigma_{3}$

\section{Discussion and conclusions}

1) Using stress tensor inversion method with fault slip data, we determined the tectonic stress field in and around Kunming basin (Figure 7). The result shows that the stress field in the study area is characterized by NNW-SSE compression, ENE-WSW extension, and strike-slip stress regimes. The maximum principal compressional stress $\left(\sigma_{1}\right)$ is oriented $335^{\circ} \sim 2^{\circ}$, with an average dip angle of $21^{\circ}$; the minimum $\left(\sigma_{3}\right)$ is oriented $44^{\circ} \sim 93^{\circ}$, with an average dip angle of $14^{\circ}$; the intermediate $\left(\sigma_{2}\right)$ has a relatively high dip angle.

2) The tectonic stress field since late Quaternary Period determined by inversion with fault slip data is consistent with the modern stress field reflected by focal mechanism solutions (JIANG et al, 2003a), suggesting stable tectonic stress field of the study area since late Quaternary Period.

3) The study area is located on the eastern Sichuan-Yunnan rhombic block and its formation of modern tectonic stress field is closely related to the uplifting of Qinghai-Tibet Plateau. The India plate moving north collided with the Eurasia plate, causing sharp uplift of the Qinghai-Tibet Plateau. As the process goes on, the Plateau continues to rise, causing lateral matter flow, which 


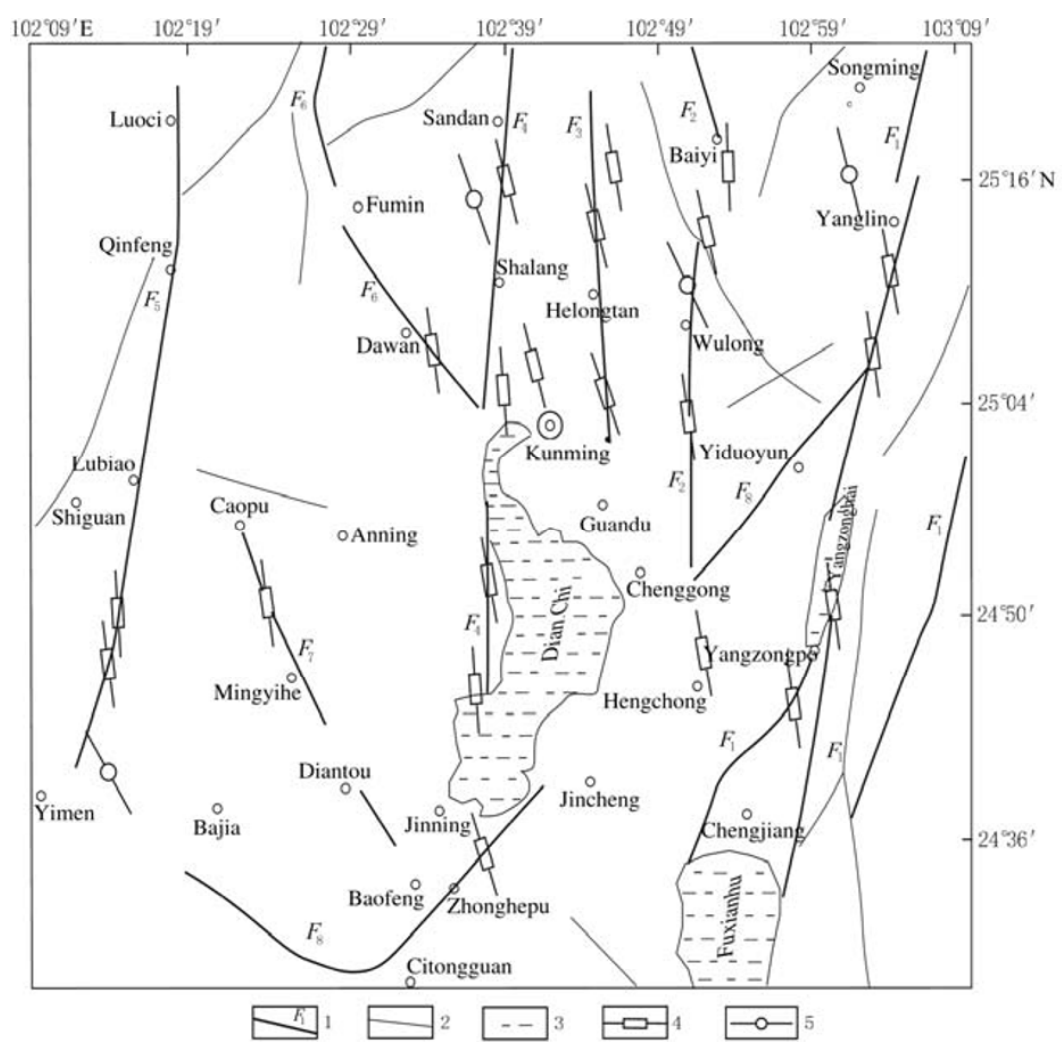

Figure 7 Tectonic stress field of the study area

1. Serial number of major fault; 2. Major fault zone; 3. Other fault; 4. Water system; 5. Orientation of principal compressional stress from fault slip data; 6 . Orientation of principal compressional stress from focal mechanism solution (JIANG et al, 2003)

then leads to the horizontal movement of crustal blocks around the Plateau. Under the action of this horizontal movement, the Sichuan-Yunnan rhombic block moves in SE-SSE direction, giving shape to the modern tectonic stress field.

\section{References}

Angdier J. 1979. Determination of the mean principal direction of stresses for a given fault population [J]. Tectonophysics, 56: 17-28.

Yamaji A, Otsubo M, Sato K. 2006. Paleostress analysis using the Hough transform for separating stresses from heterogeneous fault-slip data [J]. Journal of Structural Geology, 28(6): 980-990.

Etchecopar A, Vasseur G, Daignieres M. 1981. An inverse problem in microtectonics for the determination of stress tensors from fault striation analysis [J]. Journal of Structural Geology, 3(1): 51-55.

Gaais D, Cobbold PR, Bourgeois O, et al. 2000. Tectonic significance of fault-slip date [J]. Journal of Structural Geology, 22(7): $881-888$.

Garcia S, Angelier J, Bergerat F, et al. 2002.Tectonic analysis of an oceanic transform fault zone base on fault-slip date and earthquake focal mechanism; the Husavik-Platey Fault zone, Iceland [J].Tectonophysics, 344(3/4);157-174.

HE Hong-lin, FANG Zhong-jing, LI Ping. 1993. A preliminary approach to the fault activity of southern segment on Xiaojiang west branch fault [J]. Journal of Seismological Research, 16(3): 291-298 (in Chinese).

JIANG Chao-song, ZHOU Rui-qi, HU Yao-xiong. 2003a. Features of geological structure for Kunming basin [J]. Journal of Seismological Research, 26(1): 67-74 (in Chinese).

JIANG Chao-song, ZHOU Rui-qi, WANG Shao-jin. 2003b. Forming model and evolution of Kunming basin [J]. Journal of Seismological Research, 26(2): 172-175 (in Chinese).

QIAO Xue-jun, WANG Qi, DU Rui-lin. 2004. The current crustal deformation characteristic of active blocks in Sichuan-Yunnan region [J]. Chinese J Geophys, 47(5): 805-811 (in Chinese).

SHEN Jun, WANG Yi-peng, SONG Fang-min, et al. 1997. The NE-trending faults and block structure in the central section of the Xiao- 
jiang fault zone [J]. Seismology and Geology, 19(3): 203-210 (in Chinese).

TANG Wen-qing, LIU Yu-ping, CHEN Zhi-liang, et al. 2006. Modern activity in the southern and central parts of the Xiaojiang fault inYunnan [J]. Sedimentary Geology and Tethyan Geology, 26(2): 21-24 (in Chinese).

WANG Shao-jin, LONG Xiao-fan, YU Qing-kun. 2005. Analysis on recent tectonic stress field in the Yunnan region [J]. Journal of Seismological Research, 28(2): 178-184 (in Chinese).

XIE Fu-ren and LIU Guang-xun. 1989. Analysis of neotectonic stress field in area of the central segment of Altun fault zone, China [J]. Earthquake Research in China, 5(3): 26-36 (in Chinese).

XIE Fu-ren, LIU Guang-xun, LIANG Hai-qing. 1994. Recent tectonic stress field in northwest Yunnan Province and its adjacent areas [J]. Seismology and Geology, 16(4): 329-338 (in Chinese).

XIE Fu-ren, SU Gang, CUI Xiao-feng, et al. 2001. Modern tectonic stress field in southwestern Yunnan, China [J]. Acta Seismologica Sinica, 14(1): 18-24 (in Chinese).

XIE Fu-ren, ZHU Jing-zhong, LIANG Hai-qing, et al. 1993. Basic characteristics of recent tectonic stress field in southwest China [J]. Acta Seismologica Sinica, 6(4): 843-856.

XU Zhong-huai and GE Shu-mo. 1984. Stress field in the Fuyun, Xinjiang earthquake fracture zone determined by fitting fault slip vector data [J]. Acta Seismologica Sinica, 6(4): 395-404 (in Chinese).

YU Wei-xian, XIE Ying-qing, ZHANG Jian-guo, et al. 2004. Age studies of major active faults around Kunming basin [J]. Journal of Seismological Research, 27(4): 357-362 (in Chinese).

ZHANG Yue-qiao, SHI Wei, LIAO Chang-zheng, et al. 2006. Fault kinematic analysis and change in late Mesozoic tectonic stress regimes in the peripheral zones of the Ordos basin, North China [J]. Acta Geologica Sinica, 80(5): 639-647 (in Chinese). 